
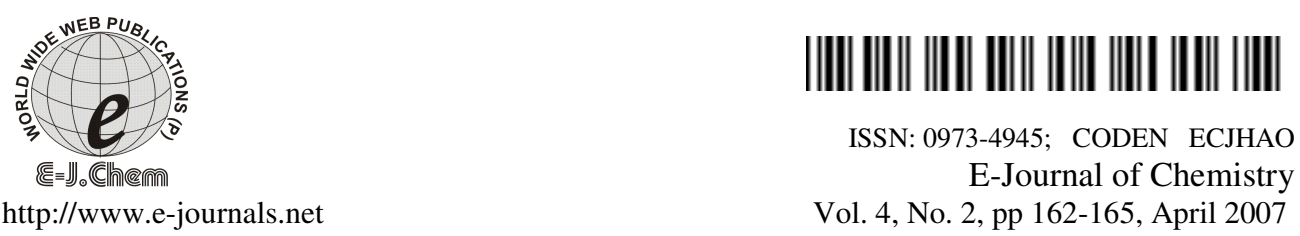

\title{
Study on Some Physico-Chemical Characteristics of Ground Water of District Rampur - A Statistical Approach
}

\author{
SUSHEEL KUMAR SINDHU* and AMIT SHARMA \\ Department of Chemistry, \\ S.S.V. (PG) College, HAPUR- 245101 (Ghaziabad), India. \\ Email: susheelsindhu@yahoo.co.in
}

Received 16 October 2006; Revised 24 November 2006; Accepted 1 December 2006

\begin{abstract}
A systematic study has been carried out to explore the water quality index of ground water of various tehsils of Rampur district. Twenty five water samples from tube wells, open wells and hand pumps at various locations were collected and analyzed for $\mathrm{pH}$, nitrate, turbidity, total dissolve solid, chlorides, total hardness, alkalinity and fluoride. In this study overall water quality of Rampur district is very poor and unsuitable for drinking purpose. Water quality of Bilaspur, Shahabad and Rampur city shows that water may not be used for drinking as well as domestic purpose. Present study recommends that the top priority should be given to water quality monitoring and indigenous technologies should be adopted to make water fit for drinking after treatment such as defluoridation, desalination.
\end{abstract}

Keywords: Physico-Chemical Characteristics, Ground water, Rampur, Statistical approach

\section{Introduction}

Water is one of the five elements described in "SHASTRA" to form life. In the known planets, our earth (the blue planets) is only blessed by the existence of water hence the life survives here. Pure water means that the water collected from a properly protected sources and subjected to an adequate system of purification, which must be free from visible 
suspended matter, color, odor and taste devoid of an objectionable bacteria and contain no dissolved matter of mineral or organic origin otherwise the water quality would be dangerous to health. Water pollution means when insoluble solid particles, soluble salts, sewage garbage, low level radioactive substances, industrial wastes, algae, bacteria, etc. go into water, water gets polluted ${ }^{1}$. This type of pollution is called water pollution. Water fit for human consumption is called drinking water or "potable water". Water that is not specifically made for drinking, but is not harmful for humans when used for food preparation is called safe water ${ }^{2}$.

The District Rampur is located between Longitude 78-0-54 \& 69-0-28 East and Latitude 28-25 \& 29-10 North. Spread in area of $2367 \mathrm{Km}^{2}$ falls in Moradabad Division of Uttar Pradesh State with a population of approximately four millions (Fig. 1). It is surrounded by district Udham Singh Nagar in North, Bareilly in East, Moradabad in West and Badaun in South. Situated on the national highway 24, the state capital is $302 \mathrm{~km}$ in East and national capital is $185 \mathrm{~km}$ in West. Rampur district has available only 5\% surface water and 95\% ground water. In Rampur tube wells, open wells, and hand pumps are parts of ground water and some river and tanks (about 1\%) are part of surface water. However, due to the fast growing urbanization of the city around 174 industries and 12850 small scale industries mainly includes the dyeing and colouring, distillery, etc. industries were set up.

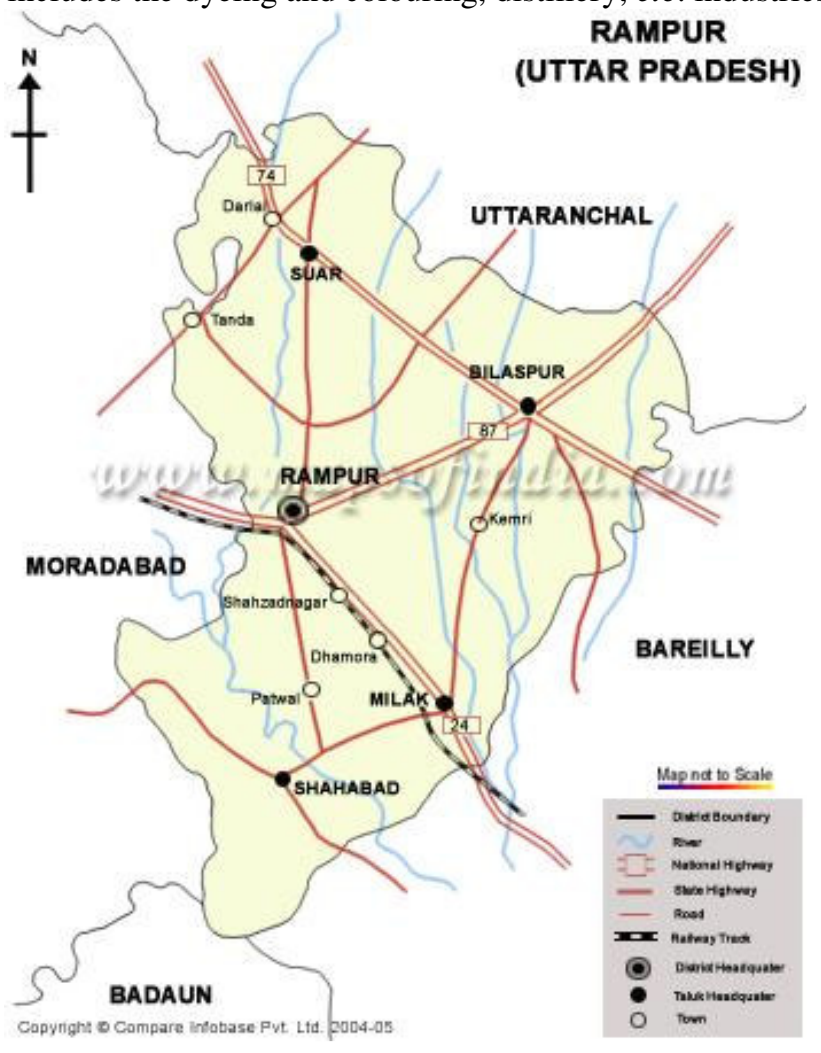

Figure 1. Map of Rampur City. 
All parameters of water viz., $\mathrm{pH}$, salinity, total dissolved solid, calcium hardness, magnesium hardness, fluoride, nitrate, etc. should be in fixed concentration. Most of the population of the district is poor and not aware about the drinking water quality and uses the available water only. Thus facing the problem of water born diseases like fluorosis, ulcer gastrointestinal troubles, etc. The study definitely will result in evolution of some cheap technology or alternative method to improve the water quality. Thus, the hygienic conditions of water are very poor in urban and rural areas of Rampur district. The main objective of this study is to identify and analyze the harmful water quality parameters of rural areas of Rampur district.

\section{Experimental}

Twenty-five water samples were collected from tubewells, openwells and handpumps. Out of these, five samples were collected from each tehsil namely Milak, Shahabad, Rampur, Suar and Bilaspur. The present study is aimed to calculate water quality index (WQI) of ground water sources of district Rampur. All the samples were examined for nine major parameters viz. $\mathrm{pH}$, nitrate, turbidity, total dissolve solid, chlorides, total hardness, alkalinity and fluoride as per standard methods ${ }^{1,3-5}$.

Water quality index - The concept of WQI to represent gradation in water quality was first proposed by Horten ${ }^{6}$. Water quality index indicates a single number like a grade that expresses the overall water quality at a certain area and time based on several water quality parameters. It is also defined as a rating reflecting a composite influence, on overall quality of water, of a number of water quality parameters. But the uses of water are manifold and quality of water required for each use varies tremendously. The main purpose of WQI is to turn complex water quality data into information that is understandable and usable by the public. It gives the public a general idea of the possible problem with water in a particular region.

Calculations of water quality index (WQI) - In first step, we calculated unit weight (Wi) of each water quality parameters by using the formula

$$
\mathrm{W} i=\mathrm{k} / \mathrm{S} i
$$

Where $\mathrm{k}=$ proportionality constant, $\quad \mathrm{Si}=$ standard desirable value of $i^{\text {th }}$ parameter

In second step, the sub index $(\mathrm{Q} i)$ is calculate as:

Where,

$$
\mathrm{Qi}=100[(\mathrm{Vi}-\mathrm{Vo} / \mathrm{Si}-\mathrm{Vo})]
$$

$\mathrm{V} i=$ concentration of $i^{\text {th }}$ parameters in the analyzed water.

$\mathrm{S} i=$ standard desirable value of $i^{\text {th }}$ parameter

$V_{0}=$ Actual value of this parameters in pure water.

Generally actual values $\mathrm{Vo}_{\mathrm{o}}=0$ of pure water for the most parameters except $\mathrm{pH}$. (for $\mathrm{pH}$ actual value is 7)

According to first and second step, WQI is calculated as follows:

$$
\text { WQI = WiQi / Wi }
$$

Table 1. Water quality index scale

\begin{tabular}{cccccc}
\hline WQI & $0-25$ & $26-50$ & $51-75$ & $76-100$ & Above 100 \\
\hline Water quality & Excellent & Good & Poor & Very poor & Unsuitable \\
\hline
\end{tabular}




\section{Results and Discussion}

Parameter wise BIS standards assigned unit weights, water quality parameters, Sub index and water quality index are listed in table no. 1. In the present study, we have analyzed twenty-five water samples from various sources including tube well, open well and hand pumps of different tehsils of Rampur district. Table-2 shows that some of the parameters are within the limit as per the BIS standards ${ }^{2}$. The observed range of WQI is 80.71 to 460.7 in the Rampur district. It has been found that the WQI of Suar tehsil is lowest and their water quality is slightly good compare to other tehsils. Water quality index of Milak is found to be very poor in water quality because their WQI is 94.32, which is high compare with water quality index scale. The values of WQI for Shahabad, Rampur and Bilaspur are 232.7, 181.02 and 460.7, respectively.

\section{Table-2}

\begin{tabular}{cccccc}
\hline Tehsil $\rightarrow$ & Milak & Shahabad & Suar & Rampur & Bilaspur \\
\hline WQI & 94.32 & 232.7 & 80.71 & 181.02 & 460.7 \\
Water quality & Very poor & Unsuitable & Very poor & Unsuitable & Unsuitable \\
\hline
\end{tabular}

In these tehsils water quality of drinking water sources are not suitable for drinking purpose. In Bilaspur, Rampur and Shahabad tehsils all the analyzed water sources are in high concentration of Alkalinity, Total dissolved solid, Chloride, Calcium hardness, Magnesium hardness, Fluoride and Nitrate. So there WQI values are very high and water quality is completely unsuitable for drinking purpose. Above cited results shows that the overall water quality of Rampur district is very poor and unsuitable for drinking purpose. Water quality of Bilaspur, Shahabad and Rampur city reveals that water may not be used for drinking as well as domestic purpose.

\section{Recommendations}

Top priority should be given to water quality monitoring and surveillance, low awareness about the importance of water quality at all levels is a major constraint. Traditional water harvesting devices should be encouraged like baories, kunds, etc. All traditional water harvesting devices of Rampur district should be rejuvenation. The indigenous technologies should be adopted to make water fit for drinking after treatment such as defluoridation, desalination, etc. The hand pump attached defluoridation plants based on activated alumina should be generated. The safe drinking water in quality-affected areas could also be provided by sanctioning schemes based on surface water sources.

\section{Acknowledgements}

The authors are thankful to the Head, Department of Chemistry, S.S.V. (PG) College, Hapur for providing laboratory facilities. The authors are also thankful to Dr. Himanshu Agarwal, Executive Editor, Asian Journal of Chemistry for his constant help and encouragement in carrying out this work.

\section{References}

1. APHA 1992, Standard methods for the examination of water and waste water. $16^{\text {th }}$ ed. American Public Health Association, New York.

2. BIS, Bureau of Indian Standards, Drinking Water Standards IS: 10500. 1993.

3. Veera Bhadram K, Ravichandra M and Prashanthi M, Nature Environ. Pollut. Tech. 2004, 3, 65.

4. Patil N J, Patil D B, Lokhande P B and Mujawar H A, Indian J. Environ. Protect. 2006, 26, 169.

5. Sinha D K and Saxena R, Indian J. Environ. Protect. 2006, 26, 163.

6. Horten R K, J. Water Pollut. Control. Fed. 1965, 3, 300. 


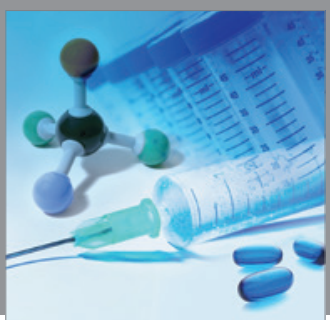

International Journal of

Medicinal Chemistry

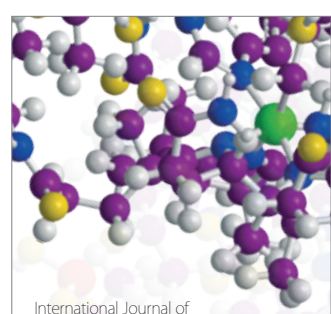

Carbohydrate Chemistry

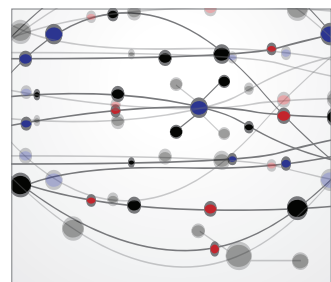

The Scientific World Journal
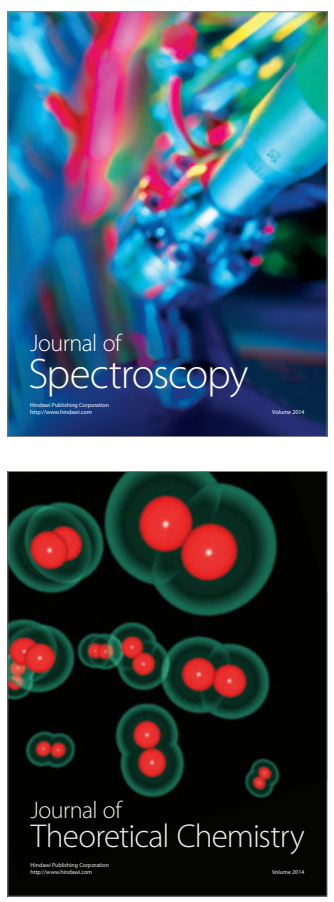
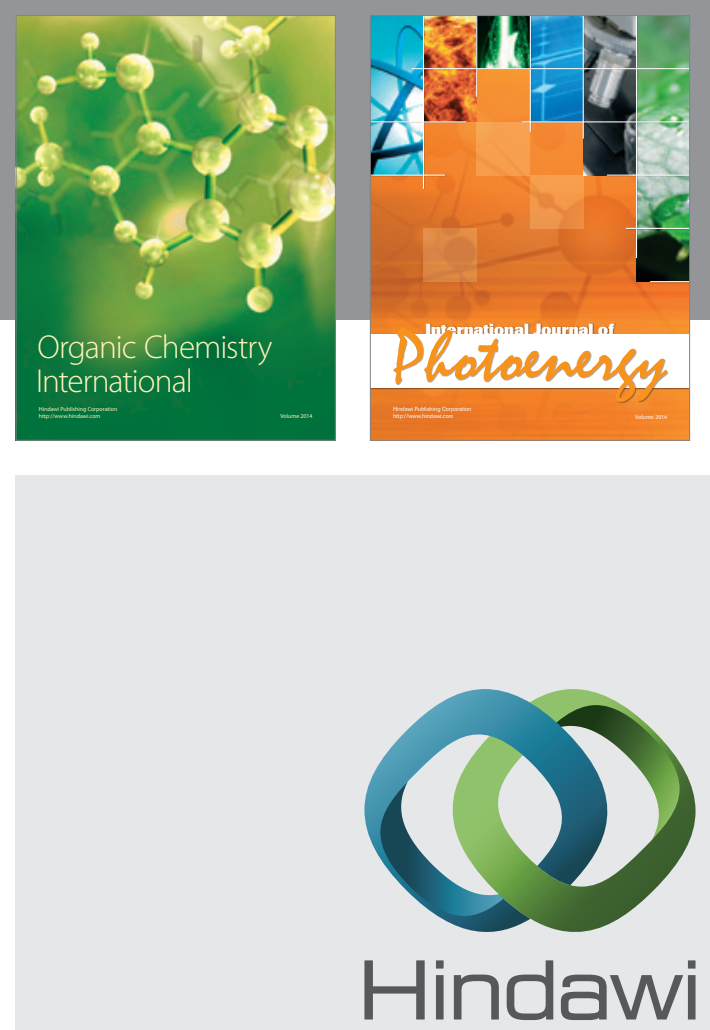

Submit your manuscripts at

http://www.hindawi.com
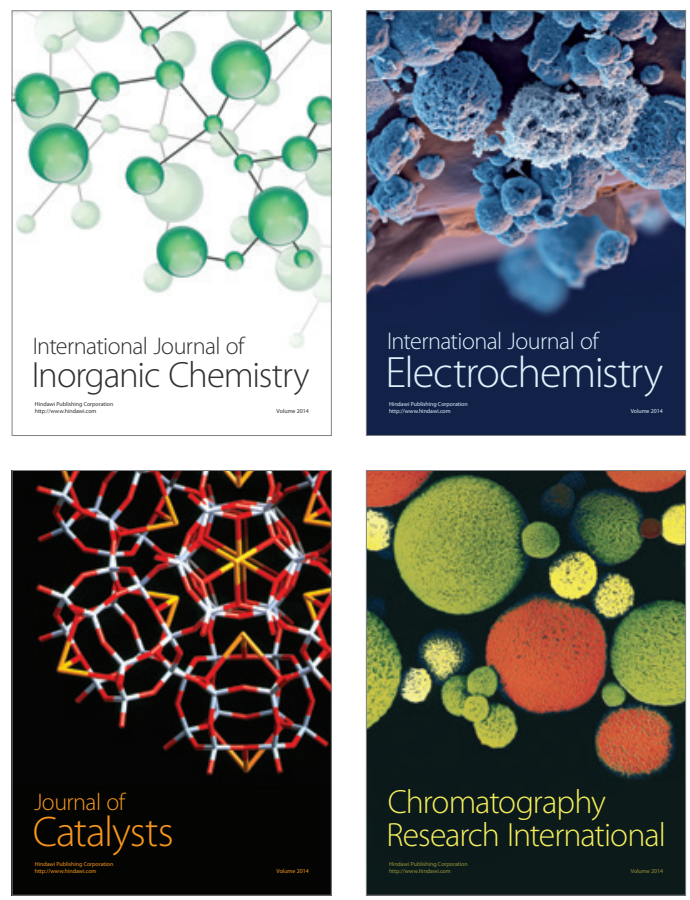
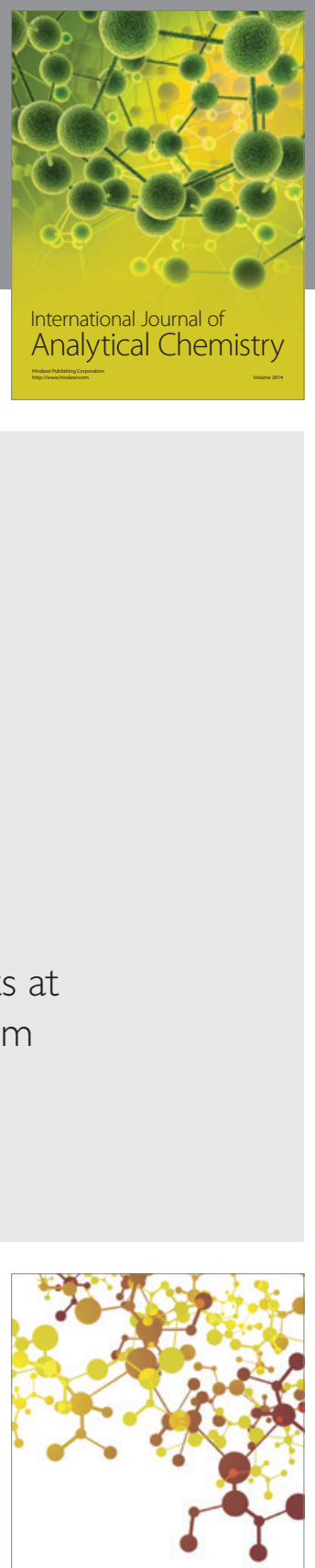

Journal of

Applied Chemistry
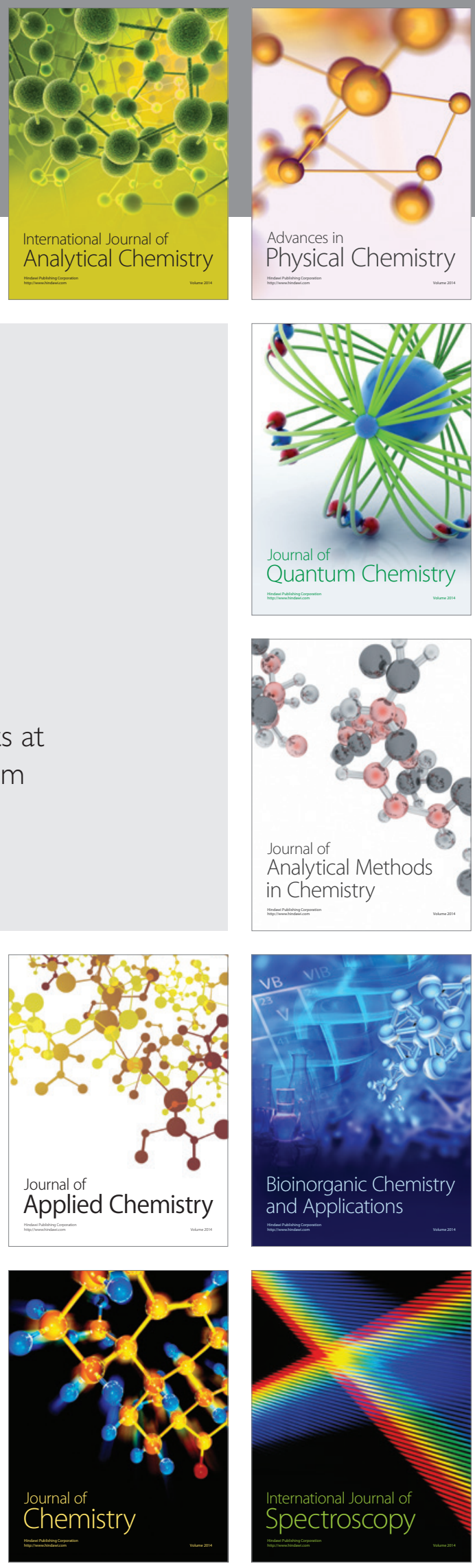